\title{
A.JOTE
}

African Journal of Teacher Education

ISSN 1916-7822. A Journal of Spread Corporation

Volume 82019 Pages 194-217

\section{Professionalism, Urban Settings, and Teachers' Self-Efficacy in Developing Countries: A Ghanaian Perspective}

\author{
Nora Bakabbey Kulbo, Bernard Gumah, \& Prince Clement Addo \\ School of Management and Economics \\ University of Electronic Science and Technology of China \\ Qingshuihe Campus
}

\begin{abstract}
In achieving the goals of education, it is imperative for teachers to have high self-efficacy which has a direct positive effect on their delivery and for the overall benefit of their pupils. This study was in threefold. First was to access the influence of teachers' demographics on their self-efficacy. Second, how work environment influences teachers 'self-efficacy and finally, how their self-efficacy impact students' performances in the Bolgatanga municipality of Ghana. The efficacy dimensions studied are classroom management practices, classroom instructional practices and student engagement. It was noted that whiles gender has no significant impact on teachers' self-efficacy, older, more educated and highly experienced teachers had higher self-efficacy. Also, teachers in the urban area tend to have higher self-efficacy than those in the rural areas. Not overlooking other factors, students' poor performance in some rural areas can largely be attributed to the lower self-efficacy of their teachers as compared to their urban counterparts. Governments should intensify their extrinsic motivation packages to make life more comfortable for teachers working in rural areas and by bridging the rural-urban developmental gap. It is also imperative to intensify self-efficacy in teacher trainees to increase their self-confidence where ever they find themselves.
\end{abstract}

Key words: self-efficacy; classroom management; instructional strategies; student engagement, urban, rural, Bolgatanga, Ghana. 


\section{INTRODUCTION}

A Teacher's efficacy is defined as a teacher's "judgment of his or her capabilities to bring about desired outcomes of student engagement and learning, even among those students who may be difficult or unmotivated" (Bandura, 1999, p. 169). Self-efficacy is considered as one's belief in the likelihood of goal completion and can be motivating in itself (Van der Bijl \& Shortridge-Baggett, 2002). 'Selfefficacy also refers to people's judgements about their capability to perform particular tasks. Taskrelated self-efficacy increases the effort and persistence towards challenging tasks; therefore, increasing the likelihood that they will be completed' (Barling \& Beattie, 2003 p.41).

Self-efficacy beliefs are an essential aspect of human motivation and behaviour as well as influence the actions that can affect one's life. Self-efficacy has an influence on people's ability to learn, their motivation and their performance. This is because people will often endeavour to learn and accomplish only those task in which they consider that they will be effective (Lunenburg, 2011). More specifically relevant to this study is the view that teacher efficacy can be said to be "teachers' confidence in their ability to promote students' learning" (Hoy, 2000). With self-efficacy, it is more likely that individuals will participate in events for which they have high self-efficacy and unlikely to engage in those they do not.

Several studies attribute the falling standards of students' academic performance in Northern Ghana to factors such as poverty, lack of access roads, water and electricity. Lack of school infrastructure and educational resources, conflict among others have also been identified (Schoon \& Boone, 1998; Action Aid Ghana, 2002; Akyeampong, 2004; and Akyeampong, Djangmah, Oduro, \& Seidu, 2007). These factors are directly related to the level of development of a locality (level of urbanisation). Teachers' self-efficacy has been identified in various studies in different parts of the world as a contributor to students' performance. Many of these studies attribute teachers' level of efficacy to their experience, level of education, job stress, gender and leadership style of heads of schools (Klassen, \& Chiu, 2010). However, urbanisation and location have not been investigated as single contributors to teacher self-efficacy. A few studies that link location to teachers' self-efficacy have produced contradicting findings. Durowoju \& Onuka, (2015) postulate that teachers' self-efficacy and location of schools as stand-alone factors have their individual effects on students' achievement in Economics but collectively have no significant effect on students' performance. Gowrie, \& Ramdass 
(2014), noted that there was a moderate to strong correlation between the demographic (including teaching experience) and school-level teacher efficacy factors, however, there were no significant differences in the three dimensions of teacher efficacy according to school type, gender, location, size of school and years of teaching experience.

In Ghana and many other developing countries, there is a sharp contrast between the living conditions in urban and rural areas preventing qualified teachers from accepting posting to rural areas. Teachers working in low socioeconomic environments (rural areas) are likely to be ranked with low self-efficacy. A comprehensive study, especially from a developing country, therefore, will solidify the influence of factors like Location of school, Experience and Professional training on teachers' selfefficacy. There is the need to take a second look at how the self-efficacy of teachers in deprived (rural areas) schools affect the performance of their students. Lack of qualified teachers in these areas is a challenge to meeting the country's educational goals and the Millennium Development Goal (MDGs) Two (Liimatainen, 2013). This study, therefore, focused on how urbanisation (teachers' place of work) and (their) professional training affect teacher's self-efficacy and its impact on student performance. The efficacy dimensions studied are classroom management practices, classroom instructional practices and student engagement strategies in line with the Teachers' Sense of Efficacy questionnaire, known as the Ohio State teacher efficacy scale (OSTES),(Tschannen-Moran \& Woolfolk Hoy, 2001).

\section{SELF-EFFICACY THEORY}

Self-efficacy beliefs are an essential aspect of human motivation and behaviour as well as influence the actions that can affect one's life. Bandura (1995) explains that self-efficacy "refers to beliefs in one's capabilities to organize and execute the courses of action required to manage prospective situations" (p. 2). Basically, self-efficacy is what a person believes he can do using his abilities under certain conditions (Snyder \& Lopez, 2007). Self-efficacy has been understood to be a task-specific form of self-esteem (Lunenburg, 2011). The basic principle behind the Self-Efficacy Theory is that people will prefer to engage in programs for which they have high self-efficacy and not likely to engage in activities they do not have high efficacy (Van der Bijl \& Shortridge-Baggett, 2002). Accordingly, people behave in the ways that portray their fundamental beliefs; in this sense, self-efficacy acts as a self-gratifying prophecy (Gecas, 2004). For example, employee A has high capability and years of experience in the creation of graphs but is not confident that he can create a high- quality graph for an 
important conference. Employee B has an average ability and only a small amount of experience in creating graphs yet has great confidence that she can work hard to create a high-quality graph for the same conference. Because of Employee A's low self-efficacy for graph creation, he lacks the motivation to create one for the conference and tells his supervisor he cannot complete the task. Employee B, due to her high self-efficacy, is highly motivated, works overtime to learn how to create a high-quality graph, presents it during the conference, and earns a promotion. Self-efficacy has an influence on the individual's motivation, ability to learn, and performance, as people will frequently endeavour to learn and perform only those task for which they believe they will be successful. In this regard, we agree with existing literature that emphasizes that efficacy is task specific and other environmental and organizational factors (Tschannen-Moran, Hoy, \& Hoy, 1998). Judgments of selfefficacy are generally measured along three basic scales: magnitude, strength, and generality (Lunenburg, 2011). Mahatma Gandhi succinctly captures the theory in the following quotation:

Man often becomes what he believes himself to be. if I keep on saying to myself that I cannot do a certain thing, it is possible that I may end by really becoming incapable of doing it. On the contrary, if I have the belief that I can do it, I shall surely acquire the capacity to do it even if I may not have it at the beginning'.-Mahatma Gandhi. (Gandhi, 2012).

There are four sources of information that people use to evaluate their efficacy: vicarious experiences, performance outcomes (performance accomplishments), physiological feedback (emotional arousal) and verbal persuasion (Bandura, 1977). These constituents assist individuals in determining if they believe in their capability to achieve precise tasks. Williams and Williams (2010) are of the view that "individuals with high levels of self-efficacy approach difficult tasks as challenges to master rather than as threats to be avoided" (p. 455).

\section{The relationship between Self-Efficacy and Performance}

Self-efficacy theory states that the combination of the four sources of developing self-efficacy (vicarious experiences, mastery experience, verbal persuasion, and physiological feedback) and the three assessment processes used to interpret self-efficacy (the analysis of task requirements, attributional analysis of experience, and assessment of personal and situational resources/constraints (Gist \& Mitchell, 1992) are essential. This will determine ones' level of self-efficacy which directly 
affects his or her performance outcomes. This is referred to as an individual's determination of what it takes to perform a task (Gist \& Mitchell, 1992).

\section{METHOD}

\section{Study area}

This study was carried out in Bolgatanga, the district capital of the Bolgatanga Municipality, and regional capital of the Upper East. The location of the Upper East Region is in the northeastern corner of Ghana and borders Burkina Faso to the North and Togo to the East. The pattern of settlement in the area is dominated by rural dwellers who are estimated at 95\% (Rondini \& Krugu, 2009). The 2010 population and housing census reports that $64.6 \%$ of the population aged 11 and above are literates. The illiteracy rate is higher among females (42.6\%) than among males $(27.2 \%)$. The data further suggest that among the population who attended school, three out of five $(59.8 \%)$ had only a primary education with more females $(63.0 \%)$ than males $(57.0 \%)$. The data shows that the same fraction of males and females reported having completed secondary/vocational/technical or post-secondary education. More of whom were males $(14.1 \%)$ compared to females (8.5\%) attained up to tertiary level of education. Out of the regional average of children aged 6 years and over who have never attended school (71.8\%), Bolgatanga has recorded the lowest rate of $61.2 \%$ (GSS, 2014).

The Human Development Report of 2011, shows that at all levels of the educational system, teachers who were not trained constituted a considerable percentage of the total number of teachers, particularly the kindergarten, in the 2007/2008 academic year. The ratio of untrained to trained teachers in the kindergarten slightly improved from 3.4 in 2005/2006 to 2.1 in 2007/2008; while the number of trained teachers per untrained teachers declined at the primary and Junior High School (JHS) levels from 2.2 in 2005/2006 to 1.8 in 2007/2008 at the primary level, and from 4.6 in 2005/2006 to 2.6 in 2007/2008 at the JHS level. Enrolment at the kindergarten level improved by 4.6\% between 2005/2006 and 2007 and 2008, while the primary and JHS enrolments increased 5\% and $2.4 \%$ respectively (UNDP, Ghana 2011).

\section{Participants}

Data Collection Method 
Data was collected and analysed from 198 teachers from basic public schools in the Bolgatanga Municipality. The questionnaire, largely adopted from the OSTES questionnaire which uses a Likert scale to measure the self-efficacy of teachers in instructional strategies, classroom management and student engagement activities, was administered (Tschannen-Moran et, al., 1998). Respondents measured their abilities using strongly disagree (1) to strongly agree (5). A total of 198 teachers from public basic schools responded to the questionnaires out of the 260 sampled. This represents $76 \%$ response rate. It is noted from Table 1 that females dominated the staff population in the basic schools in the Bolgatanga municipality and this is reflected in the random sampling with more than half $(53.5 \%)$ of the responding teachers being females. The staff is more youthful with about two-thirds (62.215) younger than 45 years. Only $6.06 \%$ are more than 55 years old. This is a development that has a toll on the staff retention in the Bolgatanga municipality as more of the younger staff seek further education and greener pastures. Staff turn-over is therefore on the ascendency in the region. A few years ago the Ghana Education Service engaged a substantial number of untrained-high school hands, especially for the rural areas. This trend seems to be declining. With random sampling, there were only $4.04 \%$ respondents with SSSCE/WASSCE certificates (equivalent to high school certificate). 26.26\% cert ' $\mathrm{A}$ ', 38.38\% with diplomas. Eighteen percent have bachelor degrees whilst $8.58 \%$ hold master degrees. Even though the Ghana Education Service (GES) is determined to retain only trained teachers in the classroom, about a quarter $(25.73 \%)$ of the respondents were not professionally trained teachers. The respondents were with varied teaching experiences with over two-thirds falling between 5 to 15 years range of teaching experience. More of these respondents teach in the rural settlements of the Bolgatanga Municipality.

\begin{tabular}{llll}
\hline Variables & Categories & Frequency $(\mathrm{N})$ & Percentage $(\%)$ \\
\hline Age & Below 25 & 19 & 9.59 \\
& $25-34$ & 68 & 34.34 \\
& $35-44$ & 36 & 18.18 \\
& $45-54$ & 53 & 26.76 \\
Gender & 55 and above & 12 & 6.06 \\
& Male & 92 & 46.46 \\
Educational Qualification & Female & 106 & 53.53 \\
& SSSCE/WASSCE & 8 & 4.04 \\
\hline
\end{tabular}




\begin{tabular}{llll}
\hline & Teacher's cert A & 52 & 26.26 \\
Diploma & 76 & 38.38 \\
Bachelor & 36 & 18.18 \\
& Masters & 17 & 8.58 \\
Professionally trained & Others & 9 & 4.54 \\
& Yes & 127 & 64.14 \\
Teaching Experience & No & 71 & 35.85 \\
& Less than 5yrs & 26 & 13.13 \\
& 5-10yrs & 72 & 36.36 \\
& $11-15$ yrs & 58 & 29.29 \\
Location of work & 16-20yrs & 28 & 14.14 \\
& More than 20 & 11 & 5.55 \\
\hline
\end{tabular}

Table 1: Demographic Characteristics of Respondents

Procedure

The sample size obtained for the study was 260 Basic school teachers, sampled from a total of 812 teachers in the municipality (2015 GES Headcount). The sample size was determined using Yerman's formula for calculating sample size taking into consideration a confidence level of $95 \%$ and a $5 \%$ margin of error. The participating schools were selected using a simple random sampling technique of which the circuit supervisors with the permission of the municipal director of education balloted with a simple "YES or NO". Only the circuits with YES were selected for the study. All teachers in the circuits selected took part in completing the questionnaire.

\section{Instrumentation}

There are a number of efficacy measurement tools existing in research. The work by the RAND organization rooted in Rotter's social learning theory is one of the earliest known tools. They included internal and external factors as motivated by a work done by Rotter (1966). It indicated that the external environment affects teacher's ability to have an impact on a student's learning. It also considered students home environment as a major factor. 
Gibson and Dembo (1984) developed a 30-item measure of teacher efficacy. They came out with what they termed as personal teaching efficacy (PTE) and general teaching efficacy (GTE). Tschannen-Moran, Hoy, \& Hoy, (1998) later proposed an integrated model. They built on the conceptual view and the propositions from Bandura and Gibson and Dembo. They went on and proposed new areas based on the four sources of information about efficacy described by Bandura (1997): mastery experience, physiological arousal, vicarious experience, and verbal persuasion.

In a more recent work, teacher efficacy and its measurement according to Tschannen-Moran, Hoy, \& Hoy, (1998) as a valid measure of teacher efficacy must include the assessment of personal efficiency, and a clear understanding and analysis of the task at hand. Since efficacy is task specific, it is appropriate to consider available resources and constraints that exist in particular teaching contexts. In our case, we considered the task requirement as a constant since GES has the same requirements for all its schools. Since work environment and professionalism are our main independent variables, it was deemed not fit to control these variables. This work adopted the efficacy measurement proposed by Tschannen-Moran, Woolfolk-Hoy, \& Hoy (1998) based on their cyclical nature of teacher efficacy model. The instruments focus more on the internal factors including teachers' efficacy for student engagement, instructional practices and classroom management.

\section{Analytical tools}

In analysing the data, Spearman's correlation matrix was used to establish the relationship between the demographic variables and all the three categories of efficacy dimensions. An Independent-Samples T-test was used to test how some of the efficacy dimensions differ in terms of the teachers training (professional and Non-professional), gender and location of schools (Urban or Rural). Finally, multiple regression was used in predicting some of the important variables on teachers' background data.

\section{RESULTS}

Presented in Table 2 is the independent sample T-test with Chi-square to determine whether the efficacy of classroom instructional practices is related to the gender of the teachers. The results indicate that apart from the ability of the teachers to respond to difficult questions from pupils ( $73 \%$ for the male and $53 \%$ for the female), the difference in all other variables are not statistically significant. 


\begin{tabular}{|c|c|c|c|c|c|c|c|c|}
\hline \multirow[t]{2}{*}{ Instructional practices } & \multirow[t]{2}{*}{ Group } & \multicolumn{5}{|c|}{ Percentage $(\%)$} & \multirow[t]{2}{*}{$\chi^{2}$} & \multirow[t]{2}{*}{ Sig } \\
\hline & & 1 & 2 & 3 & 4 & 5 & & \\
\hline \multirow{2}{*}{$\begin{array}{l}\text { Adjust your lessons to the pr } \\
\text { level for individual pupils }\end{array}$} & Male & 2.0 & 17.6 & 27.5 & 35.3 & 17.6 & \multirow[t]{2}{*}{6.485} & \multirow[t]{2}{*}{.166} \\
\hline & Female & 1.7 & 7.6 & 23.5 & 40.8 & 26.5 & & \\
\hline \multirow{2}{*}{$\begin{array}{l}\text { Respond implement altern } \\
\text { strategies in your classroom }\end{array}$} & Male & 2.0 & 16.0 & 24.0 & 40.0 & 18.0 & \multirow[t]{2}{*}{5.22} & \multirow[t]{2}{*}{.265} \\
\hline & Female & 0.8 & 7.6 & 21.2 & 43.6 & 26.7 & & \\
\hline \multirow{2}{*}{$\begin{array}{l}\text { Provide appropriate challenges } \\
\text { every capable pupil }\end{array}$} & Male & 2.0 & 13.7 & 23.5 & 35.3 & 25.5 & \multirow[t]{2}{*}{1.64} & \multirow[t]{2}{*}{.801} \\
\hline & Female & 0.4 & 13.9 & 21.4 & 36.1 & 28.2 & & \\
\hline \multirow{2}{*}{$\begin{array}{l}\text { Provide alternative explanc } \\
\text { when pupils are confused }\end{array}$} & Male & 2.0 & 9.8 & 19.6 & 49.0 & 19.6 & \multirow[t]{2}{*}{8.37} & \multirow[t]{2}{*}{.079} \\
\hline & Female & 0.8 & 8.8 & 22.3 & 31.1 & 37.0 & & \\
\hline \multirow{2}{*}{$\begin{array}{l}\text { Respond to difficult questions } 1 \\
\text { your pupils }\end{array}$} & Male & 2.1 & 8.5 & 16.5 & 38.1 & 34.7 & \multirow[t]{2}{*}{12.30} & \multirow[t]{2}{*}{.015} \\
\hline & Female & 0.0 & 15.7 & 31.4 & 19.6 & 33.3 & & \\
\hline \multirow{2}{*}{$\begin{array}{c}\text { Use a variety of assessi } \\
\text { strategies }\end{array}$} & Male & 2.0 & 12.0 & 24.0 & 40.0 & 20.0 & \multirow[t]{2}{*}{7.03} & \multirow[t]{2}{*}{.218} \\
\hline & Female & 1.7 & 10.2 & 26.0 & 32.3 & 29.8 & & \\
\hline \multirow{2}{*}{$\begin{array}{l}\text { Gauge pupils' comprehensior } \\
\text { what you have taught }\end{array}$} & Male & 4.0 & 8.0 & 26.0 & 38.0 & 24.0 & \multirow[t]{2}{*}{6.13} & \multirow[t]{2}{*}{.190} \\
\hline & Female & 0.4 & 10.5 & 22.7 & 36.1 & 30.3 & & \\
\hline \multirow{2}{*}{$\begin{array}{l}\text { Craft good questions for } \\
\text { pupils? }\end{array}$} & Male & 2.0 & 3.9 & 15.7 & 47.1 & 31.4 & \multirow[t]{2}{*}{3.21} & \multirow[t]{2}{*}{.668} \\
\hline & Female & 1.7 & 9.7 & 14.7 & 39.1 & 33.2 & & \\
\hline
\end{tabular}

$1=$ nothing, $2=$ very little, $3=$ little, $4=$ quite a bit, $5=$ a great deal

Table 2 Efficacy for Classroom Instructional Practices

Table 3 shows the correlation analysis of classroom instructional practices and teacher demographic variables. From Table 3, it could be noted that age correlated positively with all the variables indicating that, as the teachers grow older, they become more capable of classroom instructional practices. For example, they are able to adjust lessons to the proper level for individual pupils, $(\mathrm{r}=0.595 ; \mathrm{p}<0.01)$; respond better to challenging questions from pupils $(\mathrm{r}=0.122 ; \mathrm{p}<0.05)$ among others. The location of the school is noted to have an influence on teachers' self-efficacy. In this study, location correlated positively with all the variables under instructional activities. More significantly, teacher's in the urban areas tend to have higher efficacy for providing alternative explanations and examples when pupils are confused $(\mathrm{r}=0.447)$ and use a variety of assessment 
strategies $(0.504)$ both at $\mathrm{p}<0.01$ and for implementing alternative strategies in their classroom $(\mathrm{r}=0.422 ; \mathrm{p}<0.05)$.

Additionally, it was clear from Table 3 that the higher educational level of the teacher, the better they are in implementing classroom instructional activities. Very notable among these activities are implementing alternative strategies in the classroom $(\mathrm{r}=0.321, \mathrm{p}<0.01)$, provide alternative explanation for example when pupils are confused $(r=0.306, \mathrm{p}<0.01)$, respond to difficult questions from pupils $(\mathrm{r}=0.322, \mathrm{p}<0.01)$ and craft good questions for pupils $(\mathrm{r}=0.302, \mathrm{p}<0.01)$. This suggests that as respondents attain a high level of education and advance in age, there is a significant upward increase and improvement in respondent's ability to adjust lessons to suit students' level of understanding. This includes the teachers' ability to implement alternative strategies in the classroom, provide an appropriate challenge for pupils, provide an alternative explanation for confused pupils, and also to respond to difficult questions from pupils, using a variety of assessment strategies, assess the comprehension of lesson delivered and the ability to craft good questions for pupils.

\begin{tabular}{|c|c|c|c|c|c|c|c|c|c|c|c|c|}
\hline & Variables & 1 & 2 & 3 & 4 & 5 & 6 & 7 & 9 & 10 & 11 & 12 \\
\hline 1 & Age & 1 & & & & & & & & & & \\
\hline 2 & Location & .224 & 1 & & & & & & & & & \\
\hline 3 & Highest education & $.142^{\mathrm{b}}$ & .421 & 1 & & & & & & & & \\
\hline 4 & Professionally trained & $.226^{\mathrm{a}}$ & .122 & $.195^{\mathrm{a}}$ & & & & & & & & \\
\hline 5 & $\begin{array}{l}\text { Adjust your lessons to the } \\
\text { proper level for individual } \\
\text { pupils }\end{array}$ & $.255^{\mathrm{a}}$ & $.143^{\mathrm{a}}$ & $.320^{\mathrm{a}}$ & $.251^{\mathrm{a}}$ & & & & & & & \\
\hline 6 & $\begin{array}{l}\text { Implement alternative } \\
\text { strategies in your classroom }\end{array}$ & $.256^{\mathrm{a}}$ & $.422^{b}$ & $.321^{\mathrm{a}}$ & $.232^{\mathrm{a}}$ & $.595^{\mathrm{a}}$ & & & & & & \\
\hline 7 & $\begin{array}{l}\text { Provide appropriate } \\
\text { challenges for every capable } \\
\text { pupil }\end{array}$ & $.213^{\mathrm{a}}$ & .536 & $.168^{\mathrm{a}}$ & $.158^{\mathrm{a}}$ & $.397^{\mathrm{a}}$ & $.520^{\mathrm{a}}$ & & & & & \\
\hline 8 & $\begin{array}{l}\text { Provide } \\
\text { explanation when pupils are } \\
\text { confused }\end{array}$ & .078 & $.447^{\mathrm{a}}$ & $.306^{\mathrm{a}}$ & $.137^{\mathrm{b}}$ & $.494^{\mathrm{a}}$ & $.533^{\mathrm{a}}$ & $.448^{\mathrm{a}} 1$ & & & & \\
\hline
\end{tabular}




\section{Respond to difficult questions} from your pupils $\quad .122^{\mathrm{b}} .451 \quad .322^{\mathrm{a}} .157^{\mathrm{a}} \cdot 553^{\mathrm{a}} \cdot 545^{\mathrm{a}} .488^{\mathrm{a}} .562^{\mathrm{a}} 1$

9 Use a variety of assessment strategies $\quad .202^{\mathrm{a}} \cdot 504^{\mathrm{a}} \cdot 258^{\mathrm{a}} \cdot 135^{\mathrm{b}} \cdot 420^{\mathrm{a}} \cdot 524^{\mathrm{a}} \cdot 398^{\mathrm{a}} \cdot 473^{\mathrm{a}} \cdot 419^{\mathrm{a}} 1$

11 Gauge pupils' comprehension of what you have taught $\quad .172^{\mathrm{a}} .342 \quad .261^{\mathrm{a}} .109 \quad .480^{\mathrm{a}} .469^{\mathrm{a}} .495^{\mathrm{a}} .512^{\mathrm{a}} .508^{\mathrm{a}} .480^{\mathrm{a}} 1$

12 Craft good questions for your pupils $\quad .134^{\mathrm{b}} \cdot 125^{\mathrm{b}} \cdot 302^{\mathrm{a}} \cdot 134^{\mathrm{b}} \cdot 413^{\mathrm{a}} \cdot 463^{\mathrm{a}} \cdot 443^{\mathrm{a}} \cdot 543^{\mathrm{a}} \cdot 481^{\mathrm{a}} \cdot 493^{\mathrm{a}} \cdot 555^{\mathrm{a}} 1$

$\mathrm{N}=198$ b. Correlation is significant at the 0.05 level (2-tailed). a. Correlation is significant at the 0.01 level (2-tailed).

Table 3: Correlation of teachers' instructional activities and their demographic

In Table 4, Spearman's correlation matrix is used to analyze the association that exists between classroom management practices and teachers' demographics. The results indicated that older teachers tend to be more efficient in classroom engagement practices. Increasing age of teachers showed to be better able to establish classroom management systems $(\mathrm{r}=0.188, \mathrm{p}<0.01)$ and to calm disruptive pupils $(\mathrm{r}=0.140, \mathrm{p}<0.01)$. The educational qualification of the teacher also showed a significant positive association with how they control disruptive behaviours in class $(r=0.154, p<0.01)$, getting pupils to follow classroom rules ( $\mathrm{r}=0.188, \mathrm{p}<0.01)$, and the teachers' ability to effectively handle defiant pupils $(\mathrm{r}=0.244, \mathrm{p}<0.01)$. Those with professional training were equally better at implementing adequate measures to keep activities running $(r=-0.128, \mathrm{p}<0.05)$ and making clear expectations about pupils behaviour $(\mathrm{r}=-0.118 ; \mathrm{p}<0.05)$ though the correlation was a weak one. With regards to location and teachers' self-efficacy, teachers in the urban areas tend to have higher efficacy in establishing classroom management systems, and make clear the expectations of their students both at $\mathrm{p}<0.01$.

\begin{tabular}{|c|c|c|c|c|c|c|c|c|c|c|c|c|c|}
\hline & Variables & 1 & 2 & 3 & 4 & 5 & 6 & 7 & 8 & 9 & 10 & 1 & 12 \\
\hline 1 & Age & 1 & & & & & & & & & & & \\
\hline 2 & Location & .423 & 1 & & & & & & & & & & \\
\hline 3 & Highest Education & $.142^{\mathrm{b}}$ & $.602^{b}$ & 1 & & & & & & & & & \\
\hline 4 & Professionally Trained & $.226^{\mathrm{a}}$ & $.625^{\mathrm{a}}$ & $.195^{\mathrm{a}}$ & 1 & & & & & & & & \\
\hline
\end{tabular}

AJOTE Vol. 8 (2019), 194-217 
5 Disruptive Behaviour

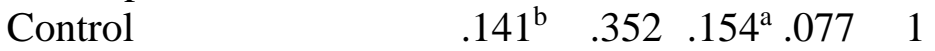

6 Follow Classroom Rules $.147^{\mathrm{b}} \quad .211 \quad .247^{\mathrm{a}} .204^{\mathrm{a}} .579^{\mathrm{a}} \quad 1$

7 Calming Disruptive

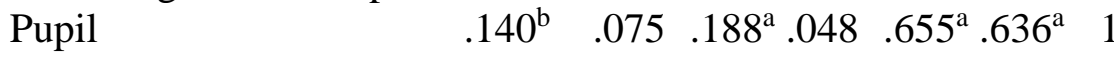

8 Establish Classroom Management System $\quad .168^{\mathrm{a}} \quad .577^{\mathrm{a}} .219^{\mathrm{a}} .097 \quad .436^{\mathrm{a}} .498^{\mathrm{a}} .532^{\mathrm{a}} \quad 1$

9 Preventing Pupil from $\begin{array}{llllll}\text { Disruption } & .107 & .523 & .235^{\mathrm{a}} .001 & .361^{\mathrm{a}} .386^{\mathrm{a}} .394^{\mathrm{a}} .415^{\mathrm{a}} & 1\end{array}$

10 Handling Defiant Pupils $\quad 089 \quad 256.244^{\mathrm{a}} .069 \quad .461^{\mathrm{a}} .350^{\mathrm{a}} .464^{\mathrm{a}} .445^{\mathrm{a}} .492^{\mathrm{a}} \quad 1$

11 Control Measures $\quad .092 \quad .425 \quad .217^{\mathrm{a}} .128^{\mathrm{b}} 469^{\mathrm{a}} \quad .496^{\mathrm{a}} .525^{\mathrm{a}} .463^{\mathrm{a}} .499^{\mathrm{a}} .516^{\mathrm{a}} \quad 1$

12 Expectations about

Pupils Behaviour $\quad .039 \quad .488^{\mathrm{a}} .162^{\mathrm{a}} .181^{\mathrm{b}} .491^{\mathrm{a}} .442^{\mathrm{a}} .499^{\mathrm{a}} .451^{\mathrm{a}} .337^{\mathrm{a}} .490^{\mathrm{a}} .566^{\mathrm{a}} 1$

$\mathrm{N}=198$, b. Correlation is significant at the 0.05 level, a. Correlation is significant at the 0.01 level (2tailed).

Table 4: Correlation of Teachers' Classroom Management Practices and their Demographic

Table 5 indicates the association between the demographic data of respondents and their efficacy for student' engagement. The teachers' efficacy for students' engagement was measured on a six-point scale. The establishment of association using Spearman's correlation coefficient showed a very weak positive association between the variables and the demographic data of the teachers. The age of the teachers was significant at 0.01 and 0.05 probability with most of the efficacy variables. The association was, however, a weak positive one. The ability to help my pupils to value learning (0.181), ability to motivate pupils who show low interest in schoolwork $(0.163)$ were significant at $\mathrm{p}<0.01$. The teachers' level of education has equally produced a weak positive association with the variables measuring the efficacy for students' engagement. The teachers believe that they can do much to get pupils to believe that they can do well in schoolwork also show a positive association of 0.243 with the level of education of the teachers. I can take adequate measures to improve the understanding of a pupil who is failing $(0.177 ; \mathrm{p}<0.01)$. On the whole, age and the educational levels of the teachers have a positive association with the teachers' efficacy for student engagement. This indicates that an increase in age and educational level to some extent cause an equal increase in the teachers' efficacy for student engagement. It must, however, be noted that despite the effect of age and education on teachers' 
classroom management, the effect is less significant in bringing an obvious change in students' progress.

$\begin{array}{lllllllllllll}\text { Variables } & 1 & 2 & 3 & 4 & 5 & 6 & 7 & 8 & 9 & 10 & 11 & 12\end{array}$

1. Age

2. Location

3. Highest Education

4. Professionally trained

5. Get pupils to believe that they can do well in schoolwork

6. Help my pupils to value learning $.176^{\mathrm{a}} 135^{\mathrm{b}} .275^{\mathrm{a}} \quad .046 .664^{\mathrm{a}} 1$

7. Motivate pupils who show low interest in schoolwork

$$
.159^{\mathrm{a}} .086 .235^{\mathrm{a}} \quad .081 .615^{\mathrm{a}} .665^{\mathrm{a}} 1
$$

8. Assist families in helping their children to do well in school

9. improve the understanding of a pupil who is failing $.227^{\mathrm{a}} .003 \quad .170^{\mathrm{a}} \cdot 114.445^{\mathrm{a}} \cdot .518^{\mathrm{a}} \cdot 550^{\mathrm{a}} 1$

$\begin{array}{lllll}.002 & .061 & .177^{\mathrm{a}} & .080 .604^{\mathrm{a}} .501^{\mathrm{a}} .591^{\mathrm{a}} .489^{\mathrm{a}} 1\end{array}$

10Do much to help my pupils think critically $\begin{array}{lllll}.067 \quad .022 .223^{\mathrm{a}} & .066 .480^{\mathrm{a}} .522^{\mathrm{a}} .487^{\mathrm{a}} .461^{\mathrm{a}} .459^{\mathrm{a}} 1\end{array}$

11Foster pupils' creativity in my classroom

$$
.119^{\mathrm{b}} .041 .165^{\mathrm{a}} .078 .546^{\mathrm{a}} .557^{\mathrm{a}} .558^{\mathrm{a}} .449^{\mathrm{a}} .554^{\mathrm{a}} \cdot 618^{\mathrm{a}} 1
$$

12Help pupils with lower abilities to understand my lessons $-.091 .006 \quad .235^{\mathrm{a}} \quad .024 .503^{\mathrm{a}} .456^{\mathrm{a}} .504^{\mathrm{a}} \cdot 385^{\mathrm{a}} .486^{\mathrm{a}} .492^{\mathrm{a}} .514^{\mathrm{a}} 1$

$\mathrm{N}=198 \mathrm{~b}$. Correlation is significant at the 0.05 level; a. Correlation is significant at the 0.01 level (2tailed).

Table 5: Correlation of teachers' Efficacy for Student Engagement and demographic

Table 6 presents the independent sample T-test of classroom instruction practices by location of work. From the results, even though there were differences in the mean rating of the items by location, only the ability of the teachers to adjust lessons to the proper level for individual pupils (M: Rural=3.49; Urban= 4.83) and the ability to implement alternative strategies (M: Rural=3.56; Urban= 4.88) were statistically significant at $p<0.05$. This suggests that, urban teachers were better off in 
adjusting their lessons to the proper levels of pupils and implementing alternative strategies in the classroom than their rural colleagues.

\begin{tabular}{|c|c|c|c|c|}
\hline Classroom Instructional Practices Items & Location & Mean & t-value & Sig. (.05) \\
\hline \multirow[t]{2}{*}{ Adjusting lessons to the proper level for individual pupils } & Rural & 3.49 & \multirow{2}{*}{2.236} & \multirow{2}{*}{.026} \\
\hline & Urban & 4.83 & & \\
\hline \multirow[t]{2}{*}{ Implement alternative strategies } & Rural & 3.56 & \multirow{2}{*}{2.163} & \multirow{2}{*}{.031} \\
\hline & Urban & 4.88 & & \\
\hline \multirow[t]{2}{*}{ Provide appropriate challenges for every capable pupil } & Rural & 3.69 & \multirow{2}{*}{.573} & \multirow{2}{*}{.567} \\
\hline & Urban & 4.78 & & \\
\hline \multirow{2}{*}{$\begin{array}{l}\text { Provide alternative explanation or example when pupils are } \\
\text { confused }\end{array}$} & Rural & 3.75 & \multirow{2}{*}{1.296} & \multirow{2}{*}{.196} \\
\hline & Urban & 4.95 & & \\
\hline \multirow[t]{2}{*}{ Respond to difficult questions from pupils } & Rural & 3.71 & & \\
\hline & Urban & 4.95 & -.449 & .152 \\
\hline \multirow{2}{*}{ Use a variety of assessment strategies } & Rural & 3.70 & \multirow{2}{*}{.512} & \multirow{2}{*}{609} \\
\hline & Urban & 4.78 & & \\
\hline \multirow[t]{2}{*}{ Gauge pupils' comprehension of what you have taught } & Rural & 3.70 & \multirow{2}{*}{986} & \multirow{2}{*}{.325} \\
\hline & Urban & 4.85 & & \\
\hline \multirow[t]{2}{*}{ Craft good questions for pupils } & Rural & 3.02 & \multirow{2}{*}{285} & \multirow{2}{*}{.776} \\
\hline & Urban & 4.97 & & \\
\hline
\end{tabular}

Table 6: T-test Analyses of Classroom Instruction Practices and Location

The T-test analysis in Table 7 establishes how the teachers' efficiency in classroom management practices differ between Rural and Urban areas. The results indicate that, despite the higher mean ratings recorded by urban teachers over the rural teachers, these differences are not statistically significant at $95 \%$ confidence interval but for only their ability to get pupils to follow classroom rules (M: Rural =3.37; Urban $=5.51 \mathrm{p}<009)$.

\begin{tabular}{lllll}
\hline Classroom Management Practices Items & Location & Mean & t-value & Sig. (.05) \\
\hline Control disruptive behaviour in classroom & Rural & 3.08 & 1.542 & .124 \\
\hline
\end{tabular}

AJOTE Vol. 8 (2019), 194-217 


\begin{tabular}{|c|c|c|c|c|}
\hline & Urban & 4.37 & & \\
\hline \multirow[t]{2}{*}{ Get pupils to follow classroom rules } & Rural & 3.37 & \multirow{2}{*}{.830} & \multirow{2}{*}{.009} \\
\hline & Urban & 4.51 & & \\
\hline \multirow[t]{2}{*}{ Calm a pupil who is disruptive or noisy } & Rural & 3.22 & \multirow{2}{*}{1.188} & \multirow{2}{*}{236} \\
\hline & Urban & 4.44 & & \\
\hline \multirow[t]{2}{*}{ Establish classroom management system } & Rural & 2.29 & \multirow{2}{*}{.570} & \multirow{2}{*}{.570} \\
\hline & Urban & 4.38 & & \\
\hline \multirow[t]{2}{*}{ Keep problem pupils from disrupting an entire lesson } & Rural & 2.16 & \multirow{2}{*}{.534} & \multirow{2}{*}{.594} \\
\hline & Urban & 4.26 & & \\
\hline \multirow[t]{2}{*}{ Handle effectively defiant pupils } & Rural & 2.37 & \multirow{2}{*}{.377} & \multirow{2}{*}{.706} \\
\hline & Urban & 4.30 & & \\
\hline \multirow[t]{2}{*}{ measures that are necessary to keep activities running } & Rural & 3.43 & \multirow{2}{*}{.388} & \multirow{2}{*}{698} \\
\hline & Urban & 4.51 & & \\
\hline \multirow[t]{2}{*}{ make expectation about pupils' behaviour clear } & Rural & 2.49 & \multirow{2}{*}{.057} & \multirow{2}{*}{.955} \\
\hline & Urban & 4.48 & & \\
\hline
\end{tabular}

Table 7: T-test Analyses of Classroom Management Practices and Location

The T-test analysis in Table 8 establishes the extent to which teachers' efficiency in student engagement differ between Rural and Urban areas. Statistically, only their ability to help pupils value learning recorded mean ratings for Rural $=3.22$ and Urban= 4.60 and significant at $\mathrm{p}<0.05$ in favour of Urban teachers. A T-test was used to establish the significance in the mean ratings of instructional strategies as applied to professionally and non-professionally trained teachers.

\begin{tabular}{llllll}
\hline Student Management Efficiency Items & Location & Mean & t-value & $\begin{array}{l}\text { Sig. } \\
\text { tailed })\end{array}$ & $(2$ \\
\hline Get pupils to believe that they can do well in schoolwork & Rural & 2.49 & -.372 & .710 \\
& Urban & 4.56 & & \\
\multirow{2}{*}{ Help my pupils to value learning } & Rural & 3.22 & & \\
& Urban & 4.60 & -2.331 & .022 \\
\hline
\end{tabular}


Motivate pupils who show low interest in schoolwork

$\begin{array}{lll}\text { Rural } & 3.47 & \\ \text { Urban } & 4.66 & -1.183\end{array}$

Assist families in helping their children to do well in school Rural

$\begin{array}{lll}4.37 \quad .895 & .895\end{array}$

Urban $\quad 4.35$

Measures to improve the understanding of a pupil failing

Rural $\quad 3.57$

$\begin{array}{llll}\text { Urban } \quad 4.35 & 1.331 \quad .187\end{array}$

Help my pupils think critically

$\begin{array}{llll}\text { Rural } \quad 2.24 & -.463 \quad .644\end{array}$

Urban $\quad 4.32$

Foster pupils' creativity in my classroom

Rural

$4.03-.854$

.394

Urban $\quad 4.50$

Help pupils with lower abilities to understand my lessons

Rural

3.59

Urban $\quad 4.54$

Table 8: T-test Analyses of Student Management Efficiency and Location

Evidence form Table 9 shows that teachers who are professionally trained to teach, employ right instructional strategies than their non-professionally trained counterparts. Statistically, professionally trained teachers adjust lessons to proper levels of individual pupils than the nonprofessionally trained ones $(\mathrm{t}=4.288, \mathrm{p}<0.001)$ and in implementing alternative strategies in the classroom ( $\mathrm{t}=4.144, \mathrm{p}<0.001)$. At $\mathrm{p}<0.05$, professionally trained teachers proved to be better at providing appropriate challenges for every capable pupil, providing an alternative explanation and example to pupils who are confused, and being able to use a variation of assessment strategies.

\begin{tabular}{llcccc}
\hline \multicolumn{2}{l}{ Variables } & $\begin{array}{l}\text { Professionally } \\
\text { trained }\end{array}$ & Mean & T-value & Sig (2-tailed) \\
\hline $1 \quad \begin{array}{l}\text { Adjust your lessons to the proper level for Yes } \\
\text { individual pupils? }\end{array}$ & No & 3.07 & 4.288 & .000 \\
2 Implement alternative strategies in your Yes \\
classroom?
\end{tabular}


Provide appropriate challenges for every No capable pupil?

4 Provide alternative explanation or example Yes when pupils are confused?

No

5 Respond to difficult questions from your Yes pupils?

No

Yes

No

7 Gauge pupils' comprehension of what you Yes have taught?

6 Use a variety of assessment strategies?

8 Craft good questions for your pupils? Yes

No
4.07

3.82

4.07

3.78

2.349

.020

3.95

3.68

$2.213 \quad .028$

3.94

3.74

4.11

3.89

\section{$1.667 \quad 097$}

1.776

.077

$\mathrm{N}=198, \mathrm{p}<0.05$

Table 9: T-test of Teachers Efficacy for Instructional Strategies on Mode of Training

In Table 10, the results of the independent T-test of teachers' efficacy for classroom management as against their mode of training (Professional or non-professional) is established. Though there were some differences in the mean ratings on accounts of the teachers' ability to control disruptive behaviour in the classroom, calming a pupil who is disruptive or noisy, establishing classroom management system with each group of pupils, keeping a few problem pupils from disrupting an entire lesson and being able to handle effectively deviant pupils were not statistically significant. However professionally trained teachers are more likely to do much to get pupils to follow classroom rules $(\mathrm{t}=3.416, \mathrm{p}<0.001)$, taking adequate measures that are necessary to keep activities running $(\mathrm{t}=2.031, \mathrm{p}<0.043)$ and the ability to always make expectation about pupils' behaviour clear to pupils $(\mathrm{t}=1.996, \mathrm{p}<0.047)$ were attributes that favours teachers who are professionally trained.

\begin{tabular}{lllll}
\hline Variables & $\begin{array}{l}\text { Professionally } \\
\text { trained }\end{array}$ & Mean & T-value tailed) \\
\hline 1 Control disruptive behaviour in the classroom & Yes & 4.42 & 1.099 & .273 \\
& No & 4.25 & & \\
\hline
\end{tabular}


2 Get pupils to follow classroom rules

Yes

No

Yes

No

4 Establish classroom management system with each Yes group of pupils

3 Calm a pupil who is disruptive or Noisy
4.80

$$
\text { No }
$$

Yes

No

7 Take adequate measures that are necessary to keep Yes activities running

No

8 Always make my expectation about pupils' Yes behaviour clear to my pupils
No
4.31

4.43

4.36

4.50

4.29

4.19

4.26

3.416

.001

$.496 \quad .620$

\section{$1.491 \quad .137$}

$-.374 \quad .709$

4.42

4.26

$1.141 \quad .255$

4.69

4.38

$2.031 \quad .043$

4.67

4.37
1.996

.047

$\mathrm{N}=198, \mathrm{p}<0.05$

Table 10: T-test of Teachers Efficacy for Classroom Management on Mode of Training

Teachers' ability to efficiently engage students as indicated in the independent T-test analysis presented in Table 11 shows that there is no statistical difference in the ratings of students' engagement as with professionally and non-professionally trained teachers. The results, therefore, indicates that, the differences as seen in the mean score are best explained as occurrences underscored by chance. Regression analysis was performed to assess the relative contribution of teachers' demographic characteristics (predictor variables) to their efficacy. We decided to adapt the most correlated and significant variables under each efficacy dimension for the regression analysis.

\begin{tabular}{llllll}
\hline & Variables & $\begin{array}{l}\text { professionally } \\
\text { trained }\end{array}$ & Mean & $\begin{array}{l}\text { Sig } \\
\text { t-value tailed) }\end{array}$ & (2- \\
\hline 1 & $\begin{array}{l}\text { I believe I can do much to get pupils to Yes } \\
\text { believe that they can do well in schoolwork }\end{array}$ & 4.66 & & \\
& No & 4.48 & 1.190 & .235 \\
\hline
\end{tabular}


2 I am able to help my pupils to value learning Yes

$$
\text { No }
$$

3 I am able to motivate pupils who show low Yes interest in schoolwork

\section{No}

$4 \quad$ I am able to assist families in helping their Yes children to do well in school

\section{No}

5 I can take adequate measures to improve the Yes understanding of a pupil who is failing

No

6 I am able to do much to help my pupils think Yes critically

7 I believe I can do much to foster pupils' Yes creativity in my classroom

\section{No}

No

8 I am able to help pupils with lower abilities to Yes understand my lessons
4.60

4.49

.761

.447

4.74

4.53

$1.425 \quad .155$

4.50

4.25

$1.681 \quad .094$

4.50

4.32

$1.193 \quad .234$

4.40

4.25

$1.009 \quad .314$

4.58

4.40

$1.200 \quad .231$

4.49

$-.520 \quad .603$

No

4.56

$\mathrm{N}=198, \mathrm{p}<0.05$

Table 11: T-test of Teachers Efficacy for Student Engagement on Professional Training

Presented in Table 12 is the model predicting the teachers' ability to adjust classroom lessons to the proper level of individual pupils. The demographics of the teachers collectively explains about $70 \%$ (adjusted $\mathrm{R}^{2}=0.704$ ) of the variance in the ability of teachers to adjust classroom lessons to the proper level of individual students. This implies that the present regression model is a good predictor of how best teachers adjust lessons to the proper level of their pupils. It follows that, professional training $(\beta=.426, \mathrm{t}=5.836, \mathrm{p}<.001)$ and location $(\beta=.318, \mathrm{t}=4.959, \mathrm{p}<.003)$ of work explain the bulk of the variance in adjusting lessons. Teachers level of experience however, has a negative relations $(\beta$ $-2.50, \mathrm{t}=-2.278$ ). This indicates that, while the increase in age, educational qualification, professional training and location (urban) cause an increase in the model, an increase in experience rather explains a decrease in this variance but not statistically significant $(\mathrm{p}<.202)$. 


\begin{tabular}{lllllll}
\hline Variables & $\mathrm{b}$ & $\beta$ & $\mathrm{R}$ & $\mathrm{R}^{2}$ & $\mathrm{t}$ & Sig.(.05) \\
\hline Constant & 33.60 & & & & 16.431 & .001 \\
Age & .225 & .072 & & 1.107 & .001 \\
What is your highest educational qualification? & 2.10 & .123 & & & 3.047 & .001 \\
Are you a professionally trained teacher? & 4.64 & .426 & & 5.836 & .001 \\
Location of School & 3.75 & .318 & & 4.959 & .003 \\
Teaching Experience & -2.50 & -.083 & & & -2.278 & .202 \\
& & & .852 & .704 & & \\
\hline
\end{tabular}

$\mathrm{N}=198$

Table 12: Regression Analysis of How Teachers Adjust Lessons to Proper Level for Individual Pupils on Teachers Demographic Data

In terms of getting pupils to follow classroom rules as indicated in Table 13, the background data of the teachers together contributed to only about $79 \%$ (adjusted $R^{2}=0.791$ ) of the variance. Professional training $(\beta=.395 ; \mathrm{t}=3.411 ; \mathrm{p}<0.01)$ and Location $(\beta=3.42 ; \mathrm{t}=3.027 ; \mathrm{p}<0.001)$ turn to be better predictors of how teachers get pupils to follow classroom rules.

\begin{tabular}{lllllll}
\hline Variables & $\mathrm{b}$ & $\beta$ & $\mathrm{R}$ & $\mathrm{R}^{2}$ & $\mathrm{t}$ & Sig.(t) \\
\hline Constant & 45.94 & & & & 8.756 & .000 \\
Age & 1.71 & .096 & & 2.056 & .020 \\
What is your highest educational qualification? & 1.87 & .104 & & & 2.348 & .001 \\
Are you a professionally trained teacher? & 4.83 & .395 & & & 3.411 & .003 \\
Location of School & 3.42 & .319 & & & 3.027 & .021 \\
Teaching Experience & -.67 & -.089 & & & -.994 & .321 \\
& & & .843 & .791 & & \\
\hline
\end{tabular}

$\mathrm{N}=198$

Table 13: Regression of Getting Pupils to Follow Classroom Rules on Teachers' Demographic Data Based on the regression model testing how best teachers help students to value learning, it came clear that the demographic characteristics of the teachers collectively explains about $80 \%\left(\mathrm{R}^{2}=.802\right)$ 
in the variance. The older the teacher $(\beta=.301, \mathrm{t}=3.825, \mathrm{p}<0.005)$, the more likely he or she is in helping pupils to value education. Similarly, more educated teachers tend to predict this model better $(\beta=.326, \mathrm{t}=4.651, \mathrm{p}<0.001)$. Notwithstanding the contributions of professional training and location, their impacts are not statistically significant predictors of this model.

\begin{tabular}{|c|c|c|c|c|c|c|}
\hline Variables & B & $\beta$ & $\mathrm{R}$ & $\mathrm{R}^{2}$ & $\mathrm{t}$ & Sig.(t) \\
\hline Constant & 31.70 & & & & 6.139 & .000 \\
\hline age & 3.02 & .301 & & & 3.825 & .005 \\
\hline What is your highest educational qualification? & 2.98 & .326 & & & 4.651 & .000 \\
\hline Are you a professionally trained teacher? & 4.01 & .216 & & & 3.259 & .796 \\
\hline Location of School & 1.33 & .075 & & & 2.810 & .419 \\
\hline \multirow[t]{2}{*}{ Teaching Experience } & -0.82 & -.087 & & & -1.244 & .215 \\
\hline & & & .927 & .882 & & \\
\hline
\end{tabular}

$\mathrm{N}=198$

Table 14: Regression of Helping Students Value Learning on Teachers' Demographic Data

\section{CONCLUSION}

Over the years, research has shown that the self-efficacy of teachers has an impact on their delivery. Whiles efficacy is more directed towards intrinsic motivation; there are some environmental factors (extrinsic) that influence teachers' efficacy. The findings pointed out that, the geographical location (rural/urban) of schools alone can make or unmake teachers' level of performance. It is important to note that, gender and experience were not so important in how efficient teachers were. The most important of these factors were level of education, location and professional training. Since age, level of education and location has a role to play; it is assumed that rural education will continue to suffer unless there are policies that increase teachers' motivation to teach in rural areas. It is also imperative to inculcate self-efficacy into the curriculum of teacher trainees to increase their self-confidence wherever they find themselves. For as long as better educated teachers seek postings to urban centers, and experienced teachers seek releases to urban centers, the disparity in development (urban and rural) continue to post a challenge. 


\section{REFERENCES}

Action Aid Ghana. (2002). Action Aid Pilot Education Survey: Draft Ghana Report. Accra: ActionAid. Article (CrossRef Link)

Akyeampong, A. K. (2004). Aid for Self-Help Effort - A sustainable alternative route to basic education in Ghana. Journal of International Cooperation in Education, 7(1), 41-52. Article $\underline{\text { (CrossRef Link) }}$

Akyeampong, K., Djangmah, J., Oduro, A., \& Seidu, A. H. (2007). Access to Basic Education in Ghana: The Evidence and the Issues. UK: Consortium for Educational Access, Transitions and Equity. Article (CrossRef Link)

Bandura, A. (1977). Self -efficacy: Toward a unifying theory of behavioral change. Psychological Bulletin, 84(1), 191-215. Article (CrossRef Link)

Bandura, A. (1995). Exercise of personal and collective efficacy in changing societies. In A. Bandura, Self-efficacy in changing societies (pp. 1-45). New York: Cambridge University. Article (CrossRef Link)

. Bandura, A. (1999). Social cognitive theory of personality. In L. A. Pervin, \& O. P. John, Handbook of personality: Theory and research (pp. 154-196). New York: New York: The Guilford Press. Article (CrossRef Link)

Barling, J., \& Beattie, R. (2003). Self-efficacy beliefs and sales performance. Journal of Organizational Behavior Management, 5(1), 41-41. Article (CrossRef Link)

Durowoju, E. O., \& Onuka, A. O. (2015). Teacher Self-Efficacy Enhancement and School Location: Implication for Students' Achievement in Economics in Senior Secondary School in Ibadan, Oyo State, Nigeria. Journal of Education and Practice, 6(11), 109-115. Article (CrossRef $\underline{\text { Link) }}$

Gandhi, M. (2012). The essential Gandhi: an anthology of his writings on his life, work, and ideas. Vintage.

Gecas, V. (1989). The social psychology of self-efficacy. Annual review of sociology, 15(1), 291316. Article (CrossRef Link)

Ghana. Statistical Service. (2014). 2010 Population and Housing Census, Bolgatanga Municipality: Upper East Region. Ghana Statistical Service. Article (CrossRef Link)

Gibson, S., \& Dembo, M.H. (1984). Teacher efficacy: A construct validation. Journal of Educational Psychology, 76, 569-582 Article (CrossRef Link) 
Gist, M. E., \& Mitchell, T. R. (1992). Self-efficacy: A theoretical analysis of its determinants and malleability. Academy of Management Review, 183-211. Article (CrossRef Link)

Gowrie, G., \& Ramdass, M. (2014). Dimensions of teacher efficacy and student academic achievement in selected primary schools in Trinidad and Tobago. British Journal of Science, Education and Culture, 123 Article (CrossRef Link)

Hoy, A. W. (2000). Changes in teacher efficacy during the early years of teaching. In annual meeting of the American Educational Research Association, New Orleans, LA Article (CrossRef Link)

Indrayan, A. (2008). Basic Methods of Medical Research (2008). Indian journal of community medicine: official publication of Indian Association of Preventive \& Social Medicine, 33(3), 208. Article (CrossRef Link)

Klassen, R. M., \& Chiu, M. M. (2010). Effects on teachers' self-efficacy and job satisfaction: Teacher gender, years of experience, and job stress. Journal of Educational Psychology, 102(3), 741756. Article (CrossRef Link)

Liimatainen, A. (2013). Millennium development goals (MDGs). In Encyclopedia of corporate social responsibility (pp. 1682-1689). Springer Berlin Heidelberg. Article (CrossRef Link)

Lunenburg, F. (2011). Self-efficacy in the workplace: implications for motivation and performance. International Journal of Management, Business, and Administration, 14(1), 46-57 Article $\underline{\text { (CrossRef Link) }}$

Rondini, S., \& Krugu, J. K. (2009). Knowledge, attitude and practices study on reproductive health among secondary school students in Bolgatanga, upper east region, Ghana. African journal of reproductive health, 13(4), 51-66. Article (CrossRef Link)

Rotter, J. B. (1966). Generalized expectancies for internal versus external control of reinforcement. Psychological Monographs, 80, 1-28.

Article (CrossRef Link)

Schoon, K., \& Boone, W. (1998). Self-efficacy and alternative conceptions of science of preservice elementary teachers. Science Education, 82(1), 553-568. Article (CrossRef Link)

Snyder, C. R., \& Lopez, S. J. (2007). Positive psychology: The scientific and practical explorations of human strengths. Thousand Oaks, CA, US: Sage Publications. Article (CrossRef Link)

Tschannen-Moran, M., Hoy, A. W., \& Hoy, W. K. (1998). Teacher efficacy: Its meaning and measure. Review of educational research, 68(2), 202-248.

Article (CrossRef Link) 
Tschannen-Moran, M., \& Hoy, A. W. (2001). Teacher efficacy: Capturing an elusive construct. Teaching and teacher education, 17(7), 783-805. Article (CrossRef Link)

UNDP, (2011) Bolgatanga Municipality Human Development Report. ARTBANC Accra Article (CrossRef Link)

Van der Bijl, J. J., \& Shortridge-Baggett, L. M. (2002). The theory and measurement of the selfefficacy construct.In E. A. Lentz, \& L. M. Shortridge-Baggett, Self-efficacy in nursing: Research and measurement perspectives (pp. 9-28). New York: Springer. Article (CrossRef $\underline{\text { Link) }}$

Williams, T., \& Williams, K. (2010). Self-efficacy and performance in mathematics: Reciprocal determinism in 33 nations. Journal of Educational Psychology, 102 (2), 453 Article (CrossRef $\underline{\text { Link) }}$ 